\title{
TIEDON MONIMUOTOISUUS
}

\author{
Max Weberin luonnehdinnan mukaan valistus on merkinnyt ennen muuta \\ maailman vapauttamista taikavoimien vallasta. Erityisesti viime \\ vuosisatoina tämä projekti on merkinnyt maailmankuvan \\ mekanisoitumista ja samalla tiedon teknistymistä. Tieto on kuitenkin \\ monimuotoista. Yksi tiedon muodoista on ns. "hiljainen tieto", joka on \\ ilmeisesti meissä vanhempaa ja alkuperäisempää kerrostumaa. Käsitel- \\ lessään tiedon monimuotoisuutta Heikki Mäki-Kulmala tähyää tiedon- \\ filosofien Aristotelesin, Weberin,Schelerin ja von Wrightin kautta myös \\ kiinteää ja "tosiolevaa".
}

HEIKKI MÄKI-KULMALA:

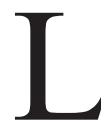

auri Viita luonnehti Moreenissaan teollisuuskaupunkia teknis-sosiaaliseksi hiiden kirnuksi, missä "matematiikan ja fysiikan lait viettivät voittojensa riemujuhlaa" ja missä "eloton ja elollinen aine noudattivat samoja lakeja", kun "samat koneet ja sama kiihkeä rytmi muokkasi puuta, kiveä, rautaa ja ihmistä”. Viidan näkemyksen ja huolen, jonka mukaan tekniikka yhtenäistää ja ohentaa maailmaa niin, ettei ihminen voi sitä enää ennen pitkää omakseen tuntea, jakavat tietysti monet muut ajattelijat ja tutkijat. Niinpä Ludwig Wittgensteinin Yleisistä huomautuksista löytyy lyhyt muistiinpano: "Hajotan, hajotan, hajotan". Filosofin itsensä mukaan tämä oli hänen ns. myöhäisvaiheensa työn punainen lanka: jossakin syvällä modernin ajattelun uumenissa oli hänen mukaansa vahingollinen pakkomielle, joka halusi kaiken ajattelun ja toiminnan yhden ja saman kaavan mukaiseksi.

Tämä yhtenäistämisen pakko oli hallinnut myös nuoren Wittgensteinin ajattelua ja niinpä Tractatuksen keskeisiä teemoja ovat esimerkiksi pyrkimys löytää lauseen ja sitä tietä ajatuksen "yleinen looginen muoto" tai teoria siitä, miten lauseet merkitsevät tai viittaavat "maailmaan". Tuskin on yllätys, että tuossa vaiheessa Wittgenstein ajatteli, kuinka kaikilla mielekkäillä lauseilla olisi yksi ja sama muoto - ja että niillä saattoi periaatteessa olla vain yksi muuttumaton ja “oikea” merkitys. Myöhäisemmässä filosofiassaan, jonka avainsanoja olivat esimerkiksi "kielipeli", "perheyhteisyys" ja "elämänmuoto", hän pyrki osoittamaan päinvastaista. Elämänsä erilaisissa tilanteissa ihmiset käyttävät kieltä hyvin eri tavoin: lasten lorut, rukoukset, käskyjen antaminen, poliittinen väittely, toisen hellittely tai luonnontieteellinen tutkimusraportti ovat kaikki erilaisia kielipelejä tai niiden osia. Miksi typistää ihmisen elämää julistamalla jotkut niistä "vääriksi" tai epäoleellisiksi - tai vastaavasti korottamalla joku niis-

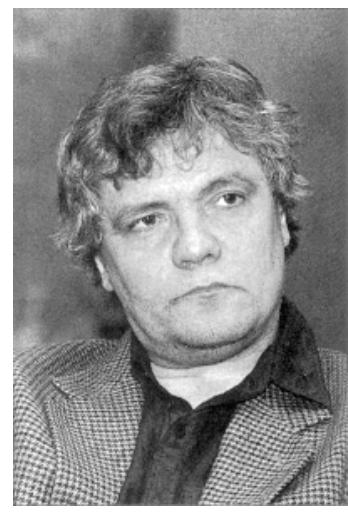

Heikki Mäki-Kulmala tä ihanteeksi kaikelle muulle.

Tässä artikkelissa pyritään tarkastelemaan tiedon monimuotoisuutta ja samalla perusteella käsitystä, ettei kaikkea voida palauttaa yhteen ja samaan "tekniseen" tekemättä väkivaltaa itse asialle, tiedolle. Myös teknisen tiedon käsitettä pyritään valaisemaan hieman tavanomaisesta poikkeavalla tavalla.

\section{TIEDON KLASSINEN

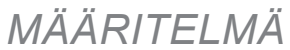

Filosofisessa keskustelussa tieto määritellään usein paikkansa pitäväksi uskomukseksi, jolla on hyväksyttävä perustelu. Tätä kutsutaan myös klassiseksi tiedon määritelmäksi ja sen alkuperäislähteeksi mainitaan usein Platonin Theaitetos- 
dialogi. Kun siis väitetään, että Kalle tietää Helsingin olevan Suomen pääkaupunki, väitetään seuraavien kolmen seikan olevan totta:

1) Kalle uskoo, että Helsinki on Suomen pää kaupunki

2) Kallella on hyväksyttävät perusteet uskoa, että Helsinki on Suomen pääkaupunki

3) Helsinki on Suomen pääkaupunki.

Nyt voimmekin jo nähdä tietämisessä piirteitä, joita ei heti tule ajatelleeksi. Ensimmäisen kohdan mukaan tieto on siis eräs laji uskomista. Kun siis ihminen tietää jonkin asian A, niin se ei ole vain ole hänen mielessään, vaan hänellä on siihen tietty asenne, jonka mukaisesti hän pitää siitä. Kun tämä on tietämisen oleellinen piirre, niin kirjan tai edes tietokoneen ei voida sanoa tietävän yhtään mitään - olipa niiden sivuilla tai muistipaikoissa miten paljon informaatioita hyvänsä.

Toinen kohta määrittelee vielä tarkemmin, minkälaisesta uskomisesta on kyse. Asiaa voidaan havainnollistaa seuraavan esimerkin avulla: Muuan pelkän kansakoulun käynyt sukulaiseni tiedusteli kerran minulta, mitä oikein tarkoitetaan, kun sanotaan, että "jokaisella algebrallisella yhtälöllä, joka sisältää tuntemattoman, on ainakin yksi juuri”. Hän oli nähnyt tuon lauseen taululle kirjoitettuna luentosalissa, jonne oli mennyt vaihtamaan sähkölamppua. Sukulaiseni uskoi tuon lauseen olevan totta, mikä pitikin paikkansa - kysehän on niin sanotusta algebran peruslauseesta. Mutta tästä huolimatta ei voida sanoa hänen tienneen tuota asiaa.

Kun tietämiseltä vaaditaan uskomisen lisäksi hyväksyttäviä perusteluita, niin tämän mukaisesti mikään täysin irrallinen "tiedonsirpale" ei olekaan todellista tietoa. Perusteltavuuden vaatimus merkitsee yksinkertaisimmillaan ja väljimmilläänkin sitä, että ihminen kykenee liittämään sirusensa hyväksyttävällä tavalla johonkin laajempaan kokonaisuuteen.

Puhuessaan "hyväksyttävistä perusteluista" kyseinen määritelmän kohta tuo tietoon myös sosiologisen ulottuvuuden. Hyväksyttävyyden kriteerit voivat nimittäin vaihdella yhteisöstä tai "kulttuurista" toiseen. Esimerkiksi algebran peruslauseeseen tutustuin ensimmäistä kertaa lukiossa, jossa opettaja mainitsi sen olemassaolosta ja keskeisestä asemasta korkeammassa matematiikassa. Tuon tunnin jälkeen me ainakin jossain mielessä tiesimme, mikä viisaus siihen kätkeytyi. Ankarasti ottaen jokin matematiikan lau- seen tietää kuitenkin vain se, joka osaa sen oikeaoppisesti todistaa.

Sanotun perusteella näyttää myös selvältä, ettei tietoa ja uskoa voida pitää toistensa sellaisina vastakohtina kuin ankaran valistushenkisessä filosofiassa on joskus tehty. Tämän vastakkainasettelun sijasta olisi paljon hyödyllisempää keskustella siitä, minkälaisissa tilanteissa ihmiseltä on syytä vaatia perusteita uskomuksilleen ja milloin hänellä on lupa "uskoa perusteettomasti”. Kaikkia uskomuksiaanhan ei yksikään ihminen voi perustella.

Määritelmän kolmas kohta lienee ainakin ensi katsomalta itsestään selvä. Kukaan ei todellakaan voi tietää esimerkiksi sellaista, että Turku on Suomen pääkaupunki - se on pelkkää luuloa.

Tiedon klassisen määritelmän pohjalle on kehitetty monia hyvin hienostuneita ja myös pitkälle formalisoituja episteemisen tai doksastisen logiikan teorioita, joiden avulla on voitu merkittävällä tavalla selkeyttää monia perinteisiä tietoteorian ja myös esimerkiksi uskonnonfilosofian kysymyksiä. Yhtenä alan klassikkona pidetään Jaakko Hintikan jo vuonna 1963 ilmestynyttä teosta Knowledge and Belief.

Edellä sanottuun on kuitenkin tehtävä eräs hyvin oleellinen muistutus: Platon ei nimittäin itse ollut halukas hyväksymään tuota hänen nimiinsä usein pantua määritelmää, koska halusi pitää tiedon ja luulon paljon radikaalimmin erillään. Tiedon kohteena olivat hänen käsityksensä mukaan vain muuttumattomat, ikuisesti voimassa olevat totuudet. Muuttuvista asioista ei voinut olla kenelläkään mitään todellista tietoa, joten viisauden rakastajienkaan ei kannattanut kiinnittää niihin erikoisempaa huomiota.

\section{PROPOSITIONAALINEN JA "HILJAINEN TIETO"}

Tiedon klassinen määritelmä nostaa esiin myös tärkeän kysymyksen siitä, onko järkevää pitää kaikkea tietoa propositionaalisena - eli onko “tietämisen akti” aina sellainen, että me ikään kuin sanomme mielessämme jonkin toden väitelauseen, mahdollisesti perusteluineen. Tämähän oli tiedon klassisen määritelmän lähtökohta, mutta onko se järkevä?

Jos tietäminen halutaan rajoittaa näihin tapauksiin, niin silloin ongelmallisiksi osoittautuvat monet kykymme tai taitomme: Pieni lapsi ei aina- 
kaan "klassisessa mielessä" tiedä miten kävellään, mutta toisaalta hän voi jo askeltaa niin, että vanhemman pitää olla katsoa joka hetki perään. Alle kouluikäiset lapset osaavat myös käyttää oikein äidinkielensä hyvinkin hienostuneita kieliopillisia muotoja, vaikka kieliopin säännöt siinä ovat vaiheessa heistä täysin käsittämättömältä.

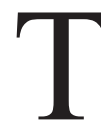

leknistyneelle kulttuurille on ominaista mo nesti sen tyyppinen intellektualismi, jon ka mukaan osaaminen olisi teoreettisen ja siis propositionaalisen - tiedon käytäntöön soveltamista. Hyvin tyypillinen tällaisen ajattelutavan edustaja oli amerikkalaisinsinööri Frederick W. Taylor. Hän uskoi, etteivät työmiehet osanneet esimerkiksi tarttua oikealla tapaa ruuvimeisseliin tai nostaa halkoa pinoon järkevimmällä mahdollisella tavalla. Erityisen koulutuksen saaneiden insinöörien tulikin ensin analysoida työprosesseja ja suunnitella sen jälkeen "parhaat mahdolliset liikeradat", jotka tuli opettaa varsinaisille suorittajille. Taylor piti aivan välttämättömänä suunnittelun ja suorittamisen - ja suunnittelijoiden ja suorittajien - ankaraa erottamista. Hänen kirjoituksistaan on helppo aistia harmistuneisuuden, jota hän tunsi niitä työläisiä kohtaan, jota hän tunsi "omista epäselvistä nyrkkisäännöistään” (Taylor 1914, 22, 47-53, 130-132.).

Tayloristit onnistuivat varmasti monin paikoin kehittämään työmenetelmiä tavalla, josta hyötyivät niin suorittajat kuin heidät palkanneet yrityksetkin. Mutta vähintään yhtä usein he tulivat yliarvioineeksi omien menetelmiensä kyvyt tuottaa päteviä ratkaisuja. Paraskin työnsuunnittelija pystyi ottamaan huomioon vain mitättömän pienen osan prosessiin vaikuttavista tekijöistä.

Osaaminen ei siis ole läheskään aina tiedostetun mallin tai kaavan käytäntöön soveltamista. Näin propositionaalisen tiedon ohella näyttäisi meillä olevan tietoa, jota emme kuitenkaan ole "saaneet sanoiksi". Niinpä sitä kutsutaankin usein hiljaiseksi tiedoksi.

On ilmeistä, että hiljainen tieto on meissä paljon vanhempi ja alkuperäisempi kerrostuma. Propositionaalinen tieto muodostaa vain tietojemme järjestelmän pintakerroksen, jonka alla sitten avautuvat hiljaisen tiedon syvyydet. Ehkä monet Taylorin halveksimat nyrkkisäännöt kumpusivatkin tuosta hiljaisesta tiedosta ja saattoivat siten olla paljon järkevämpiä kuin suunnittelijoiden aikaansaannokset.

\section{REFLEKSIIVINEN JA SPONTAANI TIETO}

Propositionaalinen tieto on läheistä sukua sille, mitä tietoteoriassa on usein kutsuttu refleksiiviseksi tiedoksi. Tällä siis tarkoitetaan sitä, että "tietämisen akti" kohdistuu aina samalla myös siihen itseensä: jos siis Kalle tietää Helsingin olevan Suoman pääkaupunki, hän myös tietää tietävänsä tämän asian. Sen sijaan hiljainen tieto ei läheskään aina tällaista. Pieni Kalle oppii jo kenties varhain huomaamaan, että on jotenkin hassua sanoa "Helsinki ovat Suomen pääkaupunki". Hän siis noudattaa subjektin ja predikaatin kongruenssisääntöä, vaikka ei tiedäkään tekevänsä niin. Voimme sanoa pienen Kallen osaavan suomen kieltä spontaanisti.

Useimmat meistä yhdistävät spontaanisuuden ja vapauden toisiinsa, mutta esimerkiksi saksalaisfilosofi G.W.F. Hegel oli asiasta kuta kuinkin päinvastaista mieltä. Hänhän totesi - tosin Spinozaa lainaten - että vapaus on välttämättömyyksien tajuamista. Ajattelu oli hänen mukaansa vapaata vain siinä määrin, kuin se oli muuttunut spontaanista reflektoivaksi, itsestään tietoiseksi.

Kun lapsi puhuu spontaanisti äidinkieltään, hän on hegeliläisen ajatustavan mukaan tuon kielen armoilla tai sen vankina. Kielen normit asettuvat häntä vastaan "mykkinä pakkoina". Refleksiivisen asenteen herääminen tarkoittaa sitä, että lapsi alkaa tajuta kielen sääntöjen sopimuksenvaraisuuden ja sanojen symbolisen luonteen. Tämä ei tapahdu yhtäkkisestä, eikä varmastikaan kieliopin opiskelun myötä. Ainakin alkuvaiheessa tärkeä merkitys on erilaisilla sanaleikeillä ja peleillä, joissa kysytään esimerkiksi "montako kirjainta on kissassa" tai "mihin avaruus päättyy".

Vapaus ei siis Hegelin mukaan ole riippumattomuutta säännöistä tai mitään sääntöjen tuolla puolen olevaa, vaan noiden sääntöjen ja välttämättömyyksien tietoista tuntemusta. (On huomattava, että Hegel puhuu kaiken aikaa ajatuksen vapaudesta. Niinpä vankileirien saariston asukas ei suinkaan ollut vapaa vielä silloin, kun hän tajusi asemansa ja sen, miksi hänet oli vangittu.) Vapauden ja välttämättömyyden suhde voidaan ilmaista myös kääntäen: Ihmistä, joka kuvittelee tekevänsä kaikki ratkaisunsa täysin itsenäisesti, on erittäin helppo hallita. Erilaiset markkinointikikat vaikuttavat varmasti kaikkein eniten "spontaaneja ostopäätöksiä" tekeviin ku- 
luttajiin (Horhheimer 1988, 180-188, Taylor 1975, 95-109).

Hegelin filosofian mukaan yksittäisen ihmisen tai koko ihmiskunnan kehitystie ei siis kulje tietämättömyydestä tietoon, vaan spontaanista tai hiljaisesta tiedosta refleksiiviseen, "itsestään tietoiseen tietoon". Kehitys ei siis koskaan ala Descartesin, Locken tai Frederick W. Taylorin kuvittelemalta "puhtaalta taululta", vaan se lähtee liikkeelle hiljaisesta tiedosta. Platonin ajatus siitä, että kaikki tieto on oikeastaan "jälleenmuistamista" (anamnesis), on myös ymmärrettävä tässä asiayhteydessä. Muuan opettaja tapasi kärjistää oman opetusfilosofiansa toteamalla kuinka "ihmiselle voi opettaa vain sitä, minkä hän jo osaa".

\section{TIETO JA INTRESSI}

Päättyneen vuosisadan loppupuoliskon eräs kaikkein vilkkainta keskustelua herättänyt filosofinen teos oli Jürgen Habermasin Erkenntis und Interesse, josta useimmille on mieleen jäänyt ajatus kolmesta erilaisesta tiedonintressistä, teknisestä, praktisesta ja emansipatorisesta. Ajatus ei suinkaan ole Habermasin itsensä keksimä, vaan se on selkeästi ja moneen kertaan ilmaistu jo esimerkiksi Aristoteleen teoksissa. Hänen mukaansahan ihmisen toimet oli mahdollista ryhmitellä kolmeen pääluokkaan: välttämättömien hyödykkeiden ja palveluiden tuottamiseen (poiesis), poliittis-yhteisölliseen toimintaan (praxis) ja mietiskelevään elämään (theoria). Näitä elämänaloja vastaavat vastasivat myös kolme erilaista tiedon lajia: tekhne, fronesis ja theoria.

Habermasin välittöminä edeltäjinä voidaan pitää ensinnäkin viime vuosisadan alkupuolella vaikuttanutta Max Scheleriä, joka omassa tiedonsosiologiassaan halusi erottaa toisistaan työtiedon (Arbeitswissen), sivistystiedon (Bildungswissen) ja pelastustiedon (Heilswissen). Hänen ohellaan on syytä mainita erityisesti praktisen tiedon (sivistystiedon, poliittis-moraalisen tiedon) omaleimaisuutta pohtineet ja korostaneet Hannah Arendt ja Hans-Georg Gadamer.

Seuraava esitys tiedon lajeista tai intresseistä noudattelee lähinnä Max Schelerin ajatuskulkuja. (Scheler 1980, 60-69.

\subsection{TYÖTIETO}

Scheler ei puhunut työtiedon yhteydessä vain työvälineistä, raaka-aineista tai tekniikasta, vaan hän koetti hahmottaa asiaa astetta yleisemmällä tasolla väittäen, että sen piirissä tarkasteltavat kohteet miellettiin mekanismeiksi.

Kaukosäätimellä varustettu televisiovastaanotin lienee meille kaikille tuttu mekanismi. Voimme valita haluamamme kanavan, mutta määrätyn napin painalluksen seurauksena lähtee liikkeelle prosessi, johon ei meillä ole valtaa: päälle kytkeytyy juuri se kanava, joka nappulan "taakse" on ohjelmoitu ja ruudusta näkyy juuri se lähetys, joka sillä hetkellä on kanavalla menossa.

Voimme nyt siirtyä konkreettisesta jonkin verran abstraktimpaan esimerkkiin: siinä on joukko valinnaisia asiantiloja, esimerkiksi $\mathrm{p}_{1}, \mathrm{p}_{2}$ ja $\mathrm{p}_{3}$, jotka puolestaan kytkeytyä esimerkiksi asiantiloihin $\mathrm{q}_{1}, \mathrm{q}_{2}, \mathrm{q}_{3}, \mathrm{q}_{4}$ ja $\mathrm{q}_{5}$ vaikkapa seuraavasti:

$$
\begin{aligned}
& \mathrm{P}_{1} \rightarrow \mathrm{q}_{1} \rightarrow \mathrm{q}_{2} \\
& \mathrm{p}_{2} \rightarrow \mathrm{q}_{3} \\
& \mathrm{p}_{3} \rightarrow \mathrm{q}_{4} \rightarrow \mathrm{q}_{5} \rightarrow \mathrm{q}_{1} \rightarrow \mathrm{q}_{2}
\end{aligned}
$$

Toimivalla agentilla a on nyt mahdollista valita vapaasti jokin vaihtoehdoista $\mathrm{p}_{1}, \mathrm{p}_{2}$ tai $\mathrm{p}_{3}$, joten mekanismi näyttää kokonaisuudessaan seuraavalta:

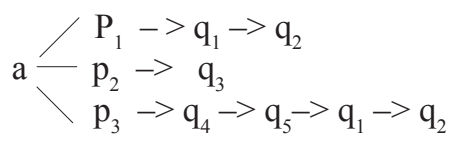

Tällaisia järjestelmiä voimme sanoa G.H. von Wrightiä mukaillen avoimiksi. (von Wright 1968 ja von Wright 1971, 60-69). Mutta koska esimerkiksi valinnan $\mathrm{p}_{2}$ jälkeen toteutuu asiantila $\mathrm{q}_{3}$ vääjäämättä (automaattisesti) niin osajärjestelmä $\mathrm{p}_{2}$ $\rightarrow \mathrm{q}_{3}$ on puolestaan suljettu. Järjestelmä pysyy suljettuna siinäkin tapauksessa, että $\mathrm{p}_{2}: \mathrm{n}$ ja sen seuraajan välinen suhde olisi satunnainen, koska siinäkään tapauksessa se ei kuitenkaan olisi agentin a "vallassa".

Moderni fysiikka, kemia ja yhä selkeämmin myös biologia mieltävät kohteensa mekanismeiksi. Mutta ajattelutapa on luonteva ja toimiva myös monilla ihmistieteen aloilla. Niinpä esimerkiksi on suositeltavaa, että taantuman uhatessa harkitaan yleisen korkotason laskua, koska sen jälkeen ihmiset ottavat halukkaammin lainaa niin kulutukseen kuin investointeihinkin, minkä seurauksena muukin taloudellinen toimeliaisuus voi elpyä. Tässäkin todellisuutta on tarkasteltiin mekanismina, jossa tietystä asiantilasta seuraa 
automaattisesti (joko varmuudella tai tietyllä todennäköisyydellä) jokin toinen asiantila.

Esimerkkitapauksessa agentti a saa nyt aikaan $\mathrm{q}_{3}:$ n tekemällä/valitsemalla $\mathrm{p}_{2}: \mathrm{n}$. Yleisemminkin todellisuuden hahmottaminen mekanismiksi liittyy pyrkimyksiin hallita sitä - agentti on silloin kiinnostunut ennen muuta saavuttamaan omat päämääränsä käyttämällä hyväksi mekanismin automaattisia "jos p niin q" -kytkentöjä.

Oleellista tälle tarkastelutavalle on myös sen rajoittuminen puhtaaseen kuvailuun: Se kertoo esimerkiksi vain, että asiantilaa $\mathrm{p}_{2}$ seuraa $\mathrm{q}_{3}$. Kaikenlaiset kysymykset siitä, "mitä tarkoitusta varten $\mathrm{q}_{3}$ seuraa $\mathrm{p}_{2}$ :ta" tai mitä "mieltä" siinä on, ovat tarkastelusta ehdottomasti poissuljettuja: tällainen tarkastelu on !'kemiallisen puhdasta" kaikista viittauksista intentioihin. Pelkästään mekanismiksi tulkittu kohde "menettää näin kaiken arvonsa" - eli työtieto tai instrumentaalinen tieto näyttäisi olevan arvovapaata hyvin moninkertaisessa mielessä.

$\mathrm{M}$ ax Weberin tunnetun luonnehdinnan mukaan valistus (Enlightenment, Die Aufklärung) on merkinnyt ennen muuta maailman vapauttamista taikavoimien vallasta (die Entzauberung). Erityisesti viime vuosisatoina tämä projekti on merkinnyt maailmankuvan mekanisoitumista edellä luonnehditussa merkityksessä. Samalla se on merkinnyt myös tiedon teknistymistä.

Mutta onko maailman mekanismiksi tulkitseva työtieto sitten ainoa järkevä tapa suhtautua todellisuuteen? Fenomenologisen filosofian edustajana Scheler suhtautui erittäin kriittisesti tällaiseen pyrkimykseen ja samalla hän tiesi, että modernilla ihmisellä on kuitenkin erittäin vahva taipumus ajatella näin. (Scheler 1980, 104-109)

Schelerin kanta oli, ettei todellisuus suinkaan paljastu mekanismiksi tieteellisen tutkimuksen kuluessa, vaan että moderni tiede tavallisesti tematisoi kohteensa mekanismiksi "jo ennen tutkimisen alkua" - tai se tutkii kohdettaan aina mekanismeina. Ongelmallisinta tässä tilanteessa nyt oli se, että kohteen tematisoituminen mekanismiksi tapahtui niin yksityisen tutkijan kuin kokonaisten instituutioidenkin tasolla täysin spontaanisti, reflektoimatta.

Scheler ja koko "fenomenologinen liike" katsoivat keskeiseksi missiokseen saattaa ihmiset tietoiseksi tuosta tematisoitumisesta sekä myös siitä, että mekanismiksi hahmottaminen ei suin- kaan ole ainoa, alkuperäisin tai "kehittynein" tapa tematisoida todellisuutta.

\subsection{SIVISTYSTIETO}

Ensimmäisinä sivistystiedon edustajina pidetään tavallisesti antiikin sofisteja. [Anja kaipasi tähän lähdettä] He olivat kaiketi Euroopan mantereella ensimmäisiä, jotka antoivat julkista opetusta ja ansaitsivat siitä myös elantonsa. Heidän ajattelutapansa ei ollut kytköksissä mihinkään erityiseen uskontokuntaan tai poliittiseen valtaryhmittymään. Sofistit opettivat sellaisia taitoja ja tietoja, jotka olivat välttämättömiä tai hyödyllisiä kenelle hyvänsä, joka pyrki kaupunkivaltion politiikassa tai halusi sen pitää.

Sofistien "oppiaineita" olivat puhe- ja väittelytaito, historia, oikeusoppi ja myös kaikki sellainen, mitä sanoisimme valtio-opiksi, kirjallisuustieteeksi ja moraalifilosofiaksi. Luonnonfilosofian tai matematiikan kysymykset eivät heitä kovin paljoa kiinnostaneet. Sofistien olivat myös tietoisesti "moderneja kaupunkilaisia", jotka eivät halunneet sitoutua vanhoihin, heimokantaisiin myytteihin tai mihinkään muihinkaan ehdottomina pidettyihin totuuksiin

Protagoraan, sofisteista kaikkein tunnetuimman, mukaan ihminen oli kaiken mitta. Tällä hän tarkoitti ennen muuta sitä, että ihmisten maailmassa puhe totuudesta, oikeudesta tai hyvästä oli kuitenkin aina vain ihmisten puhetta. Jos Jumala tai jumalat meille jotain ilmoittavatkin, niin ihmisen on kuitenkin aina tulkittava heidän viestinsä. Sofistien filosofia on siis relativismia tai skeptismiä. Protagoraan kaltaisten ajattelijoiden pyrkimyksenä oli opettaa ihmisiä elämään tässä epävarmaksi osoittautuneessa maailmassa tasapainoisesti, sivistyneesti ja toivon mukaan myös väkivallasta pidättyen.

Sokrates ja varsinkin hänen oppilaansa Platon suhtautuivat sofisteihin hyvin kriittisesti, jopa vihamielisesti. Ihminen ei ollut heille kaiken mitta ja he uskoivat myös löytäneensä ikuisten totuuksien valtakunnan, jonka "yhteyteen" ihmisen tuli elämässään pyrkiä. Tämän pyrkimyksen rinnalla olivat ne tavoitteet, joita silmällä pitäen sofistit antoivat opetustaan, täydellisen yhdentekeviä.

Platonin mukaan todellista tietoa oli vain sellainen, jonka kohdekin oli tosiolevaa (Hintikka 1969). Sellaista kreikkalaisten käsityksen mukaan saattoi taas olla vain muuttumaton ja ikuinen. Luulon kohteena olivat muuttuvat asiat - ja kaik- 
kein hatarin tai tyhjänpäiväisin luulo askarteli sellaisten asioiden kanssa, joita ihminen itse pystyi muuttelemaan. Ja sofistithan kuluttivat suurimman osan ajastaan juuri tällaisten asioiden kanssa. Käsitys, että tiedolla ja luulolla on eri kohteet, pakotti Platonin myös hylkäämään tiedon klassisen määritelmän.

Aristoteles ei voinut kuitenkaan hyväksyä Platonin jyrkkiä mielipiteitä. Ihminen oli puhuva ja poliittinen eläin, jonka hyvään elämään kuului kohtuullinen määrä osallistumista yhteisten ja myös häntä itseään koskevien ratkaisujen tekoon. Toisaalta hän kuitenkin vierasti sofistien pidäkkeetöntä relativismia ja kannatti Sokrateen ja Platonin ajatusta ideaalisesta tiedosta.

Näin Aristoteles päätyi käsitykseen, jonka mukaan ikuisten totuuksien kanssa askaroivan teoreettisen järjen (theoria) ohella on myös toisenlainen tietämisen tai viisauden muoto, jota hän luonnehti käytännölliseksi järjeksi (fronesis). Sen kohteena olivat alati muuttuvat asiat ja tilanteet, jotka eivät koskaan toistu tarkalleen samanlaisina. Käytännölliselle järjelle ominaisten ratkaisujen ei tarvinnutkaan olla päteviä "iäisyyden" tai "absoluutin" näkökannalta tarkasteltuna. Oleellisempaa esimerkiksi rauhanneuvotteluissa oli saada aikaan sopimus, jonka ehdot eri osapuolet saattoivat tietyllä hetkellä hyväksyä. On tärkeää huomata, ettei käytännöllinen järki ollut Aristoteleen mukaan mitään "käytäntöön sovellettua teoriaa", vaan tosiaankin aivan oma lajinsa.

\section{Praktinen tieto, hermeneutiikka ja reduktionismi}

Aristoteleen praktisen filosofian idealla on ollut hyvin voimakas vaikutus eurooppalaiseen sivistyshistoriaan. Hannah Arendtin, Manfred Riedelin ja eräiden muiden tutkijoiden mukaan kuitenkin jo uuden ajan alussa syntyi ajatustapoja, joiden seurauksena käsitys praktisen tiedon erityislaadusta alkoi hämärtyä. Näissä ajatustavoissa oli keskeisenä pyrkimys kehittää ihmistä tai yhteiskuntaa koskeva tiede uuden luonnontieteen esikuvien mukaisesti. Edellä ehdotetun perusteella se merkitsi sitä, että tiedon kohteet (ihminen, yhteiskunta, kulttuuri) tematisoituivat mekanismeiksi. Näin myös perinteisesti praktisen tiedon piiriin kuuluvilla aloilla olisi pitänyt ryhtyä etsiskelemään saman tyyppisiä yleisiä kausaalilakeja kuin luonnontieteissä.

Tämä kaikki johtaa vääjäämättä myös redukti- onismiin, koska mekanismin idea on ensinnäkin se, että koko systeemin käyttäytyminen voidaan selittää muutamien harvojen kausaalirelaatioiden avulla. Toinen keskeinen periaate on toistettavuus: systeemistä voidaan puhua vasta sitten, kun se toimii samoilla alkuehdoilla aina ("automaattisesti") samalla tavalla.

Osin aristotelisen praktisen tiedon perustalla, osin luonnontieteellisen ajattelutavan kritiikkinä Eurooppaan syntyi moniaineksinen perinne, jota voidaan kutsua hermeneuttiseksi. Hermeneutiikan tavoittelema ymmärrys tai tulkinta ei pyri löytämään kohteestaan mekanismia, vaan enemmän tai vähemmän tulkitsijan itsensä kaltaisen inhimillisen agentin ja/tai ne arvot, normit, instituutiot tai kulttuuriset merkityksen joiden puitteissa hän toimii. Kun inhimillistä agenttia tarkastellaan inhimillisenä agenttina, nähdään hänen toimintansa aina intentionaalisena. Georg Henrik von Wright on erityisesti kirjassaan Explanation and Understanding (von Wright 1971, 61-69) ja monissa sitä seuraavissa tutkielmissaan osoittanut kausaalisen ja intentionaalisen selityksen syvällisen eroavuuden.

Eräissä hermeneutiikan suuntauksissa vierastetaan ajatusta, että tutkittavaa kohdetta pidetään tutkijan kaltaisena. Mieluummin korostetaan "toisen toiseutta" ja sitä, ettei ymmärtämys ole koskaan täysin tyhjentävää, että toinen on toiseudessaan saavuttamaton. Painotus on hyvin aiheellinen, sillä "täydellisesti ymmärretty" kohdehan muuttuu itse asiassa mekanismiksi. Vielä radikaalimmat hermeneutiikan suuntaukset (Martin Buber, Emmanuel Levinas) haluavat puhua toisen ymmärtämisen sijasta toisen kohtaamisesta ja hänen kanssaan elämisestä niin, ettei hän millään tavalla tematisoidu kohteeksi (objektiksi).

Jo Hans-Georg Gadamerilla oli tapana korostaa, että kaikki ymmärtäminen on aina jossain mielessä “väärinymmärrystä”, koska ihmisten tulkintahorisontit eivät koskaan voi sulautua täysin yhteen - eikä tällainen sulautuminen ole edes millään tavoin tavoiteltavaa. Jacques Derridan ja eräitten muitten "dekonstruktion" filosofien mukaan tulkinnassa olisi kokonaan luovuttava tavoittemasta esimerkiksi jonkun tekstin kirjoittajan "alkuperäisiä intentioita", sitä mitä hän on tekstillään koettanut sanoa tms. Kaikki merkit tai tekstit (signifioijat) kelluvat intertekstuaalisessa universumissa kuin murskatut rypäleet käymissammioissaan... (Derrida 2002, Gadamer 1989, 270-281). 


\subsection{PELASTUSTIETO}

Platonin valtioon sisältyvää luolavertausta voidaan pitää eräänä pelastustiedon idean ylivertaisimpana esityksenä: sen tiedon tehtävä on johdattaa meidät pois harhojen luolasta. Platonin filosofian tarkoittama tieto ideamaailmasta ei oikeastaan ole ihmisen mielessä ("hänen päässään"), vaan pikemminkin filosofiaa harrastavan ihmisen sielu kohoaa tietoon, ideoiden toteen, hyvään ja kauniiseen maailmaan. Tässäkin suhteessa on ymmärrettävää, ettei Platon voinut pitää tietona ainakaan kaikkia tosia uskomuksia, joilla oli hyväksyttävä perustelu.

Oli selvää, ettei pelastustietoa tavoiteltu muutoin kuin sen itsensä takia. Samalla ilmestyi myös kreikkalaiseen ja sitä tietä koko länsimaiseen kulttuuritraditioon uudenlainen "sankarityyppi", jonka hyve tai hyveellisyys ei ollut valmistajan taitoa tai ahkeruutta, ei aristokraattiluokan sotilaallista urheutta, eikä edes sofistien opastamaa poliittista kyvykkyyttä. Uusi sankari oli filosofi, ehdottoman varman tiedon tai viisauden etsijä ja myös rakastaja. Maine, varallisuus tai menestys saattoivat olla hyvinkin yhdentekeviä asioita, ainakin hän asetti viisauden tavoittelun niiden yläpuolelle.

Kristinusko, jonka varhaiset teologit omaksuivat monia ajatuskulkuja Platonin filosofiasta, on luonteeltaan pelastususkonto. Se tosin hylkäsi filosofien ajatuksen, jonka mukaan ihminen voisi pelastua tai päästä takaisin Jumalan yhteyteen minkäänlaisen tiedon avulla, vaan se tapahtuu "yksin uskosta, yksin armosta". Tästä huolimatta ei liene kuitenkaan kovin paha kauneusvirhe nimittää kristillistä teologiaa myös yhdeksi pelastustiedon lajiksi.

Pelastustietona on eräinä aikoina saatettu pitää joskus myös sellaisia teorioita tai näkemyksiä, jotka tämän päivän ihmiselle ovat ensisijaisesti työtietoa. Matemaattisesti muotoillut luonnonlait olivat varhaisille pythagoralaisille kuten myös monille renessanssiajan oppineille jonkinlaisia Jumalan hieroglyfeja - pystyessään kuvaamaan tai selittämään jonkin luonnonilmiön matemaattisesti ihminen näki sen samalla tavoin kuin Jumala. Tämä on usein ollut esimerkiksi teknisiä sovellusmahdollisuuksia paljon voimakkaampi motiivi kehittää esimerkiksi fysiikkaa - eikä se varmaan ole kokonaan kadonnut vieläkään.

Jürgen Habermas ei puhunut Erkenntnis und Interesse -teoksessaan pelastustiedosta vaan emansipatorisesta tiedonintressistä, joka oli hä- nen mukaansa erityisenominainen psykoanalyysille ja marxismille. Hänelle, kuten varhaisemmille Frankfurtin koulun ajattelijoille "pelastustieto" oli siis negatiivis-kriittistä, joka pyrki tekemään alistamisen mekanismit näkyviksi, ei niinkään hahmottelemaan todemman ja paremman maailman ääriviivoja. Tässä suhteessa Habermasin marxismi poikkeaa radikaalisti siitä "sosialismin rakentajien valoisasta optimismista", joka oli tyypillistä esimerkiksi neuvostoideologialle. Vieläkin radikaalimpi tällaisessa "negativismissaan" oli eksistenssifilosofi Karl Jaspers, jonka mukaan "tosioleva" nousi esiin vain traagisen kautta, siinä haaksirikossa (Scheitern), joka tuli kohtaamaan ihmisen kaikkia yrityksiä tehdä maailma käsitettäväksi tai hallittavaksi. (Jaspers 1951, 65-69, Kauppi, 1989).

\subsection{INTRESSIT JA INSTITUUTIOT}

Erilaiset tiedon lajit liittyivät Schelerin - ja kaikkien muidenkin edellä mainittujen ajattelijoiden mukaan erilaisiin instituutioihin. Niin ikään niiden pätevyyden ja arvon kriteerit poikkeavat toisistaan. Ilmeisesti hän olisi nähnyt suuria ongelmia siinä, että nykyajan tiedeinstituutioita pyritään arvioimaan jonkin yhtenäisen pisteytysjärjestelmän mukaan - vaikka toisaalta hän olisi ehkä ymmärtänyt myös evaluoinnin välttämättömyyden.

Mielenkiintoinen on myös hänen käsityksensä, jonka mukaan työtieto ja sen instituutiot olisivat demokraattisia, kun taas sivistystiedolle olisi ominaista aina tietynlainen aristokraattisuus (Scheler 1980, 160-163). ${ }^{3}$ Jos nyt muistelemme jo kohta kolmen vuosikymmenen takaista opiskelijaradikalismia, niin sen keskeisiä ajatuksia olivat

a) vaatimus demokratiasta ("Mies ja ääni -periaate voimaan yliopistohallinnon kaikilla ta soilla!").

b) ajatus tieteen muuttumisesta tuotantovoi maksi.

c) ajatus tutkimuksesta ja opiskelusta samanlaisena työnä, mitä "oikeatkin" työläiset tekevät. ("Sivistysylimysten aika on ohi!") (SOL 1973)

Pelkän työtiedon piirissä nämä ajatukset ovat periaatteessa varsin toimivia, joskin demokraattisesti valitut toimielimet ovat jo nykypäivän kokemuksen valossa osoittautuneet monin paikoin liian hidasliikkeisiksi allokoimaan resursseja. 
Niinpä valtaa on haluttu usein antaa "markkinoille", mikä yliopistossa, korkeakouluissa tai jopa lukiotasolla voisi merkitä yhä lisääntyvää valinnaisuuden kasvua. Erilaiset opintokokonaisuudet olisivat hyödykkeitä ja opiskelit ja niiden ostajia ja kuluttajia.

Jos tähän ei haluta kuitenkaan kaikelta osin mennä, niin esiin nousee kysymys siitä, kuka voi sitten sanella rajoituksia sille, miten pitkälle pelkkä "koulutuskysyntä" voi yliopistojen, korkeakoulujen jne. koulutustarjontaa yms. määrätä. Tehtävän voi suorittaa vain jonkinlainen aristokratia - millä nimellä sitä sitten kutsutaankin.

\section{LOPUKSI}

Tiedon lajien moninaisuus sekä puhe dekonstruktiosta, sosiaalisesta konstruktionismista, suurten kertomusten lopusta, yhteismitattomien kielipelien moninaisuudesta, erilaisista paradigmoista ja niiden kriiseistä, etnometodologiasta tai feministisestä tieteenkritiikistä ovat hämmentäviä ainakin kahdessa hyvin vastakkaisessa merkityksessä. Yhtäältä ne voivat aiheuttaa samanlaisen huimauksen tunteen kuin Nietzschen tunnettu lausahdus, jonka mukaan me olisimme ensimmäisiä sukupolvia, joilla ei enää ole totuutta, että meillä olisi vain "näennäisyyden koko Olympos", jonka "takana" ei olisi mitään "tosiolevaa" tms. Mutta toisaalta tuon moninaisuuden kintereillä näyttää kulkevan suuren yhdenmukaistamisen aalto, joka tuntee ja tunnustaa tiedossa vain välineen ja ehkä myös jonkinlaisen uutuus- ja viihdearvon.

Aristoteleen, Schelerin ja Habermasin kolmijako on sopiva ja varsin kestäväksi osoittautunut pysähdyspaikka ja kiintopiste mainittujen ääripäiden välillä. On hyvin vaikea ajatella elinvoimaista kulttuuria, missä ei tehtäisi työtä, missä ihmisellä olisi ongelmia suhteessa itseensä ja/ tai toisiin ihmisiin ja missä ei ainakin joillekin ihmisille olisi tullut halu päästä harhojen luolasta ja tavoittaa jotakin "tosiolevaa".

\section{VIITE}

1. Hegelin ajatusten vaikutus on terminologiaa myöten selvästi nähtävissä esimerkiksi L.S.Vygotskin käsityksissä oppimisesta ja käsitteellisen ajattelun kehityksestä. Jean Piagetin oppimisteoria, johon hän on ilmeisesti päätynyt täysin Hegelistä riippumatta , sisältää hyvin paljon samanlaisia aineksia.
2. "Ajatus sofisteista ensimmäisinä humanisteina ja jossain mielessä myös 'ensimmäisinä moderneina kaupunkilaisina' ehkä vaikuttavimmin perusteltu Wilhelm Jaegerin teoksessa Paidea: die Formung der Griechischen Menschen. Erittäin hyvä tiivistelmä tästä Jaegerin käsityksestä löytyy G.H. vin Wrightin teoksesta Ajatus ja julistus, luku Kreikkalaisten humanismi. (Jaeger 1954, von Wright 1961)

3. Ajatus sivistystiedon 35aateluudesta" oli hyvin keskeinen asia myös 1930-ja 1940-lukujen nerkittävällä akateemisella vaikuttajalla, filosofi Eino Kailalla. Hän korosti usein kuinka tieteen ja taiteen tuli olla "sosiaalisen sädekehän ympäröimä”. (Kaila 1992, 420) ja koko viite: Muutama sana syvähenkisestä. teoksessa Kaila, Eino. Valitut teokset, osa 2.s. 413-429. Otava: Helsinki, 1992.

\section{LÄHTEET}

Derrida, Jacques. allekirjoitus, tapahtuma, konteksti. teoksessa Platonin apteekki ja muita kirjoituksia. Gaudeamos, 2002.

Gadamer, Hans-Georg. (1986). Wahrheit und Methode. Grundzüge einer philosophischen Hermeneutik. Tübingen: J.C.B. Mohr (Paul Siebeck). 1986.

Hintikka, Jaakko (1963). Knowledge and Belief: an Introduction to the Logic of two Notions. Ithaca : Cornell University Press.

Hintikka, Jaakko (1969). Tieto ja tiedon kohteet Platonilla. Teoksessa Hintikka, Jaakko.

Tieto on valtaa: aatehistoriallisia esseitä. WSOY.

Horkheimer, Max (1988). Zum

Rationalismussteit in der gegenwärtigen Philosophie. Teoksessa Horkheimer. Max. Gesammelte Schriften, Band 3. Frankfurt am Mein: Fischer.

Jaeger, Werner (1954). Paideia. Die Formung der Griechischen Menschen. Berlin: de Gryter.

Jaspers, Karl (1951). Der Philosophische Galube. München : Piper

SOL:n Taisteluohjelma Suomen opiskelijoille. Sosialistinen opiskelijaliitto: Helsinki 1973.

Artikkeli saapui toimitukseen 21.10.2003. Se hyväksyttiin julkaistavaksi 30.1.2004. 